\title{
Informing South African Students about Information Systems
}

\author{
Mike Hart \\ University of Cape Town, Cape Town, South Africa
}

\author{
mhart@commerce.uct.ac.za
}

\begin{abstract}
At the University of Cape Town, females and students disadvantaged under the previous South African apartheid education system are under-represented in Information Systems (I.S.) classes. This research shows that these are also the groups most ignorant about I.S. at the school-leaving stage. After being informed about the discipline through a small intervention, a significant increase in enthusiasm for majoring in and being employed in I.S. occurred. This should result in a better educational fit and greater enrolment of these groups in I.S., and reduce some switching to I.S. from other subjects at a later stage. The key influencing sources for university students'study decisions are also examined, and it is evident that a different approach is needed for each group in order to maximize the number of quality I.S. graduates.
\end{abstract}

Keywords: Information systems, education, perceptions, computers, major

\section{Introduction}

At the University of Cape Town (UCT), the Department of Information Systems has had strong growth over the last few years. Situated in the Faculty of Commerce, it has over 200 third year Information Systems (I.S.) majors and 90 fourth year (honors) students. Until the third quarter of 2001 local demand for I.S. positions has far exceeded the supply, and a large number of graduates have also taken up good job offers internationally. Research (and basic course demographics) showed that although there were similar numbers of male and female students commencing a Commerce or Business Science degree, a much lower percentage of females than males chose to major in I.S. A similar pattern existed with students whose first language was not English, and who had been disadvantaged by the previous apartheid educational system. Given the prevailing shortage of I.S. graduates it made sense to investigate why these differences existed, and to attempt to improve this situation.

This research commenced in 1998 with a study (Hart et al., 1999) carried out on students at the University of Cape Town. Some 360 students in four courses from 1st to 3rd year were questioned about the difficulty and familiarity of I.S. topics and areas, and their attitudes towards various career characteristics. It followed prior work of von Hel-

Material published as part of this journal, either on-line or in print, is copyrighted by the publisher of Informing Science. Permission to make digital or paper copy of part or all of these works for personal or classroom use is granted without fee provided that the copies are not made or distributed for profit or commercial advantage AND that copies 1) bear this notice in full and 2) give the full citation on the first page. It is permissible to abstract these works so long as credit is given. To copy in all other cases or to republish or to post on a server or to redistribute to lists requires specific permission and payment of a fee. Contact Editor@inform.nu to request redistribution permission. lens et al. (1998) in Australia. As in a number of previous studies in different countries, gender, cultural aspects and prior computer experience were found to play a significant role in responses. From 2000 onwards, further data was collected on first year students at various points of their introductory I.S. course, and in 2001 further studies were undertaken of 1 st to 4 th year university students and senior school students.

This paper focuses on an aspect of that research. It investigates the knowledge and perceptions that senior school students have of Information Systems, and how this can influence their selection of I.S. as a major at university. It shows how certain groups are more affected than others. An intervention to inform school students about I.S. is described, and the resulting differences in perceptions and in study and employment intentions are examined. The current level of switching from other majors to I.S. at university is noted, and the main influencers of decisions on enrolment in university majors are discussed. Conclusions are drawn on obtaining a better solution to the development of I.S. skills from all sectors of the South African population.

\section{Prior Research}

Much research has been carried out internationally on attitudes to computers and their use in different situations. These attitudes and the choices of whether to study in a computer-related area have often been shown to be affected by a common set of factors. Although some studies have shown no differences, gender has often been an important discriminator at school and university level (Shashaani, 1994; Taylor \& Mounfield, 1994; Corston \& Colman, 1996; Von Hellens et al., 1998, Trauth et al., 2000; Staehr et al., 2001). Females usually have a lower computer self-efficacy (Bandura, 1986; Compeau \& Higgins, 
1995; Divine \& Wilson, 1997) than males, resulting in relatively fewer wishing to study Computer Science or I.S. Culture, race and first language are also often responsible for different attitudes to computing (Martin et al., 1992; Sacks, 1993; Busch, 1995; Sensales \& Greenfield, 1995; Nielsen et al., 1997; Chrisholm et al., 1998; Gupta \& Houtz, 2000). Prior experience of some sort with computers is usually a positive influence (Knezeck et al., 1993; Gos, 1996), and the maturity of students (Nielsen et al., 1997) can play a role. The influence of teachers, family and friends (Gupta \& Houtz, 2000) is also important.

These factors are captured as demographic variables in the two studies to be discussed below.

\section{The Schools Survey}

It was apparent that many students arrived at UCT not knowing what I.S. was, or that one could study it, let alone major in it. Apart from further exploring the perceptions of university students, it was felt that a study further back in the "supply chain" could be useful. An opportunity presented itself in May 2001, when the university had an "Open Day", attended by students close to school-leaving age from local schools. Like many UCT departments, Information Systems had a display area in which to inform school attendees about their subject, and answer questions. This year they decided to provide a broader coverage of the area, with posters, brochures, typical course deliverables such as systems documentation, research reports, and a video presentation. Given the 1998 research, posters also noted the scope for creativity, and the fact that I.S. students didn't have to be male or have prior computer experience.

A questionnaire was also distributed, with a prize of free software as an incentive. It aimed to measure the knowledge and perceptions students had about I.S. and other subjects on arrival at the Open Day, and then see whether the additional information provided by the Department of I.S. had changed their knowledge or study intentions. It was designed for easy completion, largely by circling op- tions. Although the methodology has some inherent limitations regarding accuracy of the data generated, it was felt that much value could be gained by comparing the results for different subsets of the data. Students were also told to complete the form as accurately as possible, to give their personal views, and that there were no "right" answers. Forms were returned to a box manned by staff. Most of the 252 forms returned appeared to be well completed, and they came from 67 different schools.

\section{School Student Demographics}

Although the objective was to ascertain the perceptions of the school-going population as a whole regarding I.S., the primary focus was on the subgroups who were underrepresented in IS major courses, namely females and "previously disadvantaged" groups. Prior to the arrival of democracy in South Africa most students from the African (black), "coloured" and Asian groups were given separate and generally inferior education. UCT has always had a relatively large number of students from all race groups, and at present white students comprise less than half of those entering university and the Commerce Faculty. Commerce entrants are split equally between males and females. The Open Day population, and those completing the questionnaire, turned out to be skewed towards the subgroups of most interest, previously disadvantaged and female students. While this was technically unrepresentative of the total population, this did not matter when contrasting subgroups, and it provided a more efficient sample. The split was:

Gender: Females (67\%), Males (33\%)

Race: $\quad$ Black (54\%), Coloured / Asian (34\%), White $(12 \%)$

Schools: Previously Disadvantaged (62\%), Advantaged (38\%)

Grade: $\quad$ Grade 12 (final) (63\%), Grade 11(22\%), Grade $10(15 \%)$ 


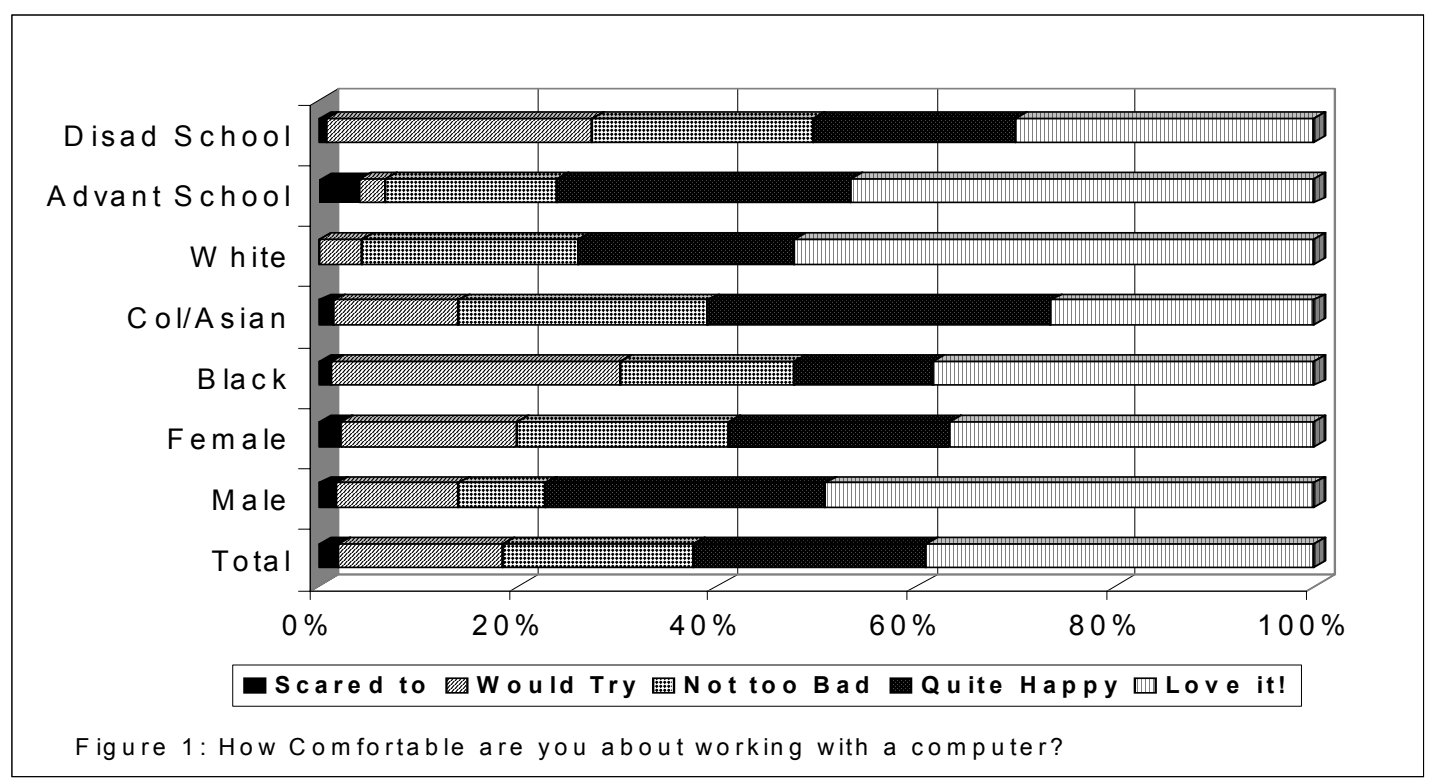

It can be seen from the above that there are now a large number of "previously disadvantaged" students attending "previously advantaged" schools. Under apartheid these schools catered only for white students, although some private schools served all races.

Responses to the first question "How comfortable are you about working with a computer?" are shown for different subgroups in Figure 1. In all cases $50 \%$ or more are "quite happy" or "love it", indicating a reasonable experience level, while virtually none are "scared to". The greatest existing usage is not surprisingly among whites in advantaged schools.

\section{Familiarity with Concepts}

The next question started "Before you came to this Open Day, had you heard of," and tested familiarity with certain terms, to see how relatively well known "Information Systems" was. Students could answer "yes", "no" or "unsure," and the "\%yes" results are shown in Table 1. Computer Studies is a school subject (taken by relatively few, mostly white students), Computer Science is a major in the Science Faculty at UCT, Information Science is only found at UCT in conjunction with Library programs, and Information Studies does not exist as a specific degree or major. All of the terms were relatively more familiar to whites, males and those from previously advantaged schools. As a group the lowest recognition came from the black (African) students. This could partially be affected by most not having English as first language. In every group Information Systems is less familiar than Computer Science, Computer Studies, Information Technology and I.T., and I.S. comes in much lower still. The percentage overall who were "unsure" (not shown here) was highest for Information Studies (24\%) and I.S. (17\%). This vali-

\begin{tabular}{|l|c|c|c|c|c|c|c|}
\hline & \multicolumn{2}{|c|}{ Gender } & \multicolumn{3}{c|}{ Race } & \multicolumn{2}{c|}{ School } \\
\hline & Fem & Male & Black & C/A & White & Disad & Advant \\
\hline Information Science & $40 \%$ & $47 \%$ & $29 \%$ & $51 \%$ & $50 \%$ & $33 \%$ & $51 \%$ \\
\hline Information Studies & $33 \%$ & $39 \%$ & $28 \%$ & $44 \%$ & $35 \%$ & $31 \%$ & $41 \%$ \\
\hline Information Systems & $\mathbf{5 5 \%}$ & $\mathbf{7 2 \%}$ & $\mathbf{4 2 \%}$ & $\mathbf{6 7 \%}$ & $\mathbf{8 8 \%}$ & $\mathbf{4 8 \%}$ & $\mathbf{7 5 \%}$ \\
\hline Information Technology & $73 \%$ & $81 \%$ & $49 \%$ & $89 \%$ & $96 \%$ & $60 \%$ & $92 \%$ \\
\hline Computer Science & $73 \%$ & $77 \%$ & $44 \%$ & $91 \%$ & $96 \%$ & $58 \%$ & $90 \%$ \\
\hline Computer Studies & $77 \%$ & $78 \%$ & $57 \%$ & $82 \%$ & $100 \%$ & $67 \%$ & $88 \%$ \\
\hline I.S. & $44 \%$ & $45 \%$ & $29 \%$ & $53 \%$ & $54 \%$ & $33 \%$ & $59 \%$ \\
\hline I.T. & $74 \%$ & $75 \%$ & $47 \%$ & $87 \%$ & $96 \%$ & $57 \%$ & $92 \%$ \\
\hline
\end{tabular}

Table 1: Percentage of each group who had heard of the above before Open Day 


\begin{tabular}{|c|c|c|c|c|c|c|c|c|}
\hline & & \multicolumn{2}{|c|}{ Gender } & \multicolumn{3}{c}{ Race } & \multicolumn{2}{c}{ School } \\
\hline Terms & All & Fem & Male & B & CA & W & Disad & Adv \\
\hline Computers & $61 \%$ & $68 \%$ & $58 \%$ & $41 \%$ & $76 \%$ & $79 \%$ & $50 \%$ & $75 \%$ \\
\hline Programs & $28 \%$ & $31 \%$ & $23 \%$ & $20 \%$ & $32 \%$ & $42 \%$ & $21 \%$ & $38 \%$ \\
\hline Software & $27 \%$ & $25 \%$ & $30 \%$ & $21 \%$ & $26 \%$ & $38 \%$ & $20 \%$ & $33 \%$ \\
\hline Business & $20 \%$ & $21 \%$ & $20 \%$ & $17 \%$ & $22 \%$ & $25 \%$ & $19 \%$ & $23 \%$ \\
\hline Processing & $17 \%$ & $15 \%$ & $22 \%$ & $8 \%$ & $18 \%$ & $33 \%$ & $8 \%$ & $28 \%$ \\
\hline Hardware & $11 \%$ & $11 \%$ & $15 \%$ & $6 \%$ & $9 \%$ & $38 \%$ & $5 \%$ & $22 \%$ \\
\hline Files & $11 \%$ & $10 \%$ & $14 \%$ & $10 \%$ & $7 \%$ & $13 \%$ & $8 \%$ & $14 \%$ \\
\hline Nothing at all & $10 \%$ & $9 \%$ & $5 \%$ & $16 \%$ & $6 \%$ & $0 \%$ & $14 \%$ & $7 \%$ \\
\hline Libraries & $7 \%$ & $5 \%$ & $9 \%$ & $12 \%$ & $3 \%$ & $0 \%$ & $9 \%$ & $4 \%$ \\
\hline Government & $1 \%$ & $1 \%$ & $1 \%$ & $0 \%$ & $1 \%$ & $0 \%$ & $1 \%$ & $1 \%$ \\
\hline
\end{tabular}

Table 2: Before Open Day, what did Information Systems mean to you?

dated our views that far fewer of the school population were aware of I.S. than of Computer Science, and showed that the disadvantaged and female members were particularly badly informed.

Respondents were also asked to circle words from a list that they would have associated with Information Systems before Open Day. Results were more conventional than might have been expected, with computers, programs, software, business and processing consistently outweighing "nothing at all", libraries and government. Hardware and files came in between, and to about $16 \%$ of the black students I.S. meant "nothing at all". (See Table 2.)

\begin{tabular}{|l|c|c|c|c|c|c|c|c|}
\hline & & \multicolumn{2}{|c|}{ Gender } & \multicolumn{3}{|c|}{ Race } & \multicolumn{2}{c}{ School } \\
\hline Major & All & Fem & Male & B & CA & W & Dis & Adv \\
\hline Accounting & $37 \%$ & $38 \%$ & $30 \%$ & $45 \%$ & $38 \%$ & $17 \%$ & $44 \%$ & $28 \%$ \\
\hline “Computers" & $27 \%$ & $24 \%$ & $32 \%$ & $34 \%$ & $21 \%$ & $29 \%$ & $33 \%$ & $21 \%$ \\
\hline Economics & $20 \%$ & $19 \%$ & $18 \%$ & $27 \%$ & $13 \%$ & $13 \%$ & $24 \%$ & $15 \%$ \\
\hline Management & $20 \%$ & $24 \%$ & $15 \%$ & $16 \%$ & $26 \%$ & $21 \%$ & $24 \%$ & $14 \%$ \\
\hline I.T. & $20 \%$ & $18 \%$ & $28 \%$ & $19 \%$ & $22 \%$ & $33 \%$ & $20 \%$ & $23 \%$ \\
\hline Information Systems & $\mathbf{1 9 \%}$ & $\mathbf{1 5 \%}$ & $\mathbf{2 6 \%}$ & $\mathbf{1 5 \%}$ & $22 \%$ & $\mathbf{2 1 \%}$ & $\mathbf{1 6 \%}$ & $\mathbf{2 3 \%}$ \\
\hline Law & $17 \%$ & $21 \%$ & $9 \%$ & $14 \%$ & $16 \%$ & $13 \%$ & $11 \%$ & $23 \%$ \\
\hline Marketing & $16 \%$ & $16 \%$ & $14 \%$ & $19 \%$ & $15 \%$ & $13 \%$ & $17 \%$ & $16 \%$ \\
\hline Psychology & $15 \%$ & $21 \%$ & $4 \%$ & $14 \%$ & $15 \%$ & $25 \%$ & $15 \%$ & $17 \%$ \\
\hline Computer Science & $14 \%$ & $12 \%$ & $20 \%$ & $12 \%$ & $12 \%$ & $25 \%$ & $11 \%$ & $21 \%$ \\
\hline Finance & $13 \%$ & $16 \%$ & $7 \%$ & $15 \%$ & $13 \%$ & $13 \%$ & $13 \%$ & $17 \%$ \\
\hline Human Resources & $11 \%$ & $15 \%$ & $4 \%$ & $7 \%$ & $16 \%$ & $4 \%$ & $13 \%$ & $6 \%$ \\
\hline
\end{tabular}

Table 3: Before Open Day, what had you thought of majoring in ? 


\section{Major Interests Prior to Open Day}

Next, respondents were asked to circle one or more subjects they had thought of majoring in before Open Day (see Table 3). "Computers" was listed as a general term, and I.T. has only in the last two years been used as a program name in the Computer Science Department, and is probably in most cases taken as a general area. Accounting, Economics, and Management Studies are other departments in the Commerce Faculty, and Human Resources, Marketing, Finance, Law and other majors are streams in Management Studies. It can be seen that relatively fewer females, black students, and those at previously disadvantaged schools intended to register for Information Systems.

\section{Value of Informing Students}

It was important to find out to what extent individual respondents had been informed by the video presentations, posters and brochures in the I.S. room at Open Day. This would be used as a mitigating variable when comparing before and after views. Roughly one third said they had both watched the presentations and read the posters or brochures, one third had done either of the two and one third neither. When asked "At Open Day, have you learnt more about: (various subjects)", students in general gave the results in the top part of Table 4. If answers are restricted to only those who had watched presentations and read the posters, the results in the lower part of Table 4 are very encouraging. The percentage learning "a lot" has increased from $32 \%$ to $60 \%$, and learning "nothing" has decreased from $22 \%$ to $3 \%$.

\section{Segmenting Students into "Informed" and "Uninformed"}

Further questions looked at current student opinions, after the input students had received from the Department of Information Systems and other departments at the Open Day. The first was "Do you want to major in I.S.?" with respondents able to answer "yes", "no" or "uncertain". To analyze the impact that the Open Day information had had, replies were carefully segmented. The pre-Open Day question had allowed students to ring one or more possible major subjects. They could, for example, have ringed Accounting and Information Systems, or Management, Marketing and Finance.

The data was split into those who had ringed I.S. before the Open Day (with or without other subjects), and those who had not ringed I.S., but had chosen other subjects. It was also split between the "informed" (those who had seen the poster or brochure data and/or watched the presentations), and the "uninformed" (those who had done neither). The "informed" who had previously not ringed I.S. were now asked whether they wanted to major in I.S., with results given in Table 5. The first part of Table 5 compares the responses of the "not informed" to the "informed" In both cases students who had said that they had not thought of doing a degree majoring in I.S. prior to the Open Day are now wishing to or are wavering. Of those that have been informed about I.S., 29\% would now like to major, and only $17 \%$ now say "no". There is a $17 \%$ swing to "yes" from the "not informed" and 36\% of them are now unsure. It could be suggested that some students indicated they wanted to major in I.S. now as they thought it would please the I.S. Department (and give them a better chance

All School Students:

\begin{tabular}{|l|c|c|c|c|c|c|}
\hline & Accounting & Economics & $\begin{array}{c}\text { Information } \\
\text { Systems }\end{array}$ & $\begin{array}{c}\text { Management } \\
\text { Studies }\end{array}$ & Statistics & $\begin{array}{c}\text { Commerce } \\
\text { Faculty }\end{array}$ \\
\hline No & $28 \%$ & $35 \%$ & $\mathbf{2 2 \%}$ & $40 \%$ & $55 \%$ & $18 \%$ \\
\hline A little & $37 \%$ & $41 \%$ & $\mathbf{4 6 \%}$ & $41 \%$ & $31 \%$ & $36 \%$ \\
\hline A lot & $35 \%$ & $25 \%$ & $\mathbf{3 2 \%}$ & $19 \%$ & $14 \%$ & $46 \%$ \\
\hline
\end{tabular}

Only Students Who Watched Presentations and Read Posters:

\begin{tabular}{|l|c|c|c|c|c|c|}
\hline & Accounting & Economics & $\begin{array}{c}\text { Information } \\
\text { Systems }\end{array}$ & $\begin{array}{c}\text { Management } \\
\text { Studies }\end{array}$ & Statistics & $\begin{array}{c}\text { Commerce } \\
\text { Faculty }\end{array}$ \\
\hline No & $29 \%$ & $31 \%$ & $\mathbf{3 \%}$ & $30 \%$ & $45 \%$ & $7 \%$ \\
\hline A little & $29 \%$ & $35 \%$ & $\mathbf{3 7 \%}$ & $34 \%$ & $34 \%$ & $40 \%$ \\
\hline A lot & $42 \%$ & $33 \%$ & $\mathbf{6 0 \%}$ & $36 \%$ & $20 \%$ & $53 \%$ \\
\hline
\end{tabular}

Table 4: At Open Day, have you learnt more about: 
Previously not majoring in I.S.

\begin{tabular}{|l|c|c|c|c|}
\hline & Total & \% Yes & $\%$ No & $\begin{array}{c}\text { \% Un- } \\
\text { sure }\end{array}$ \\
\hline Not Informed & 59 & $17 \%$ & $47 \%$ & $36 \%$ \\
\hline Informed & 100 & $29 \%$ & $17 \%$ & $54 \%$ \\
\hline
\end{tabular}

Prev. not majoring in I.S., and now "informed"

\begin{tabular}{|l|c|c|c|c|}
\hline By Previous Major & Total & \% Yes & $\%$ No & $\begin{array}{c}\text { \% Un- } \\
\text { sure }\end{array}$ \\
\hline Accounting & 38 & $39 \%$ & $13 \%$ & $47 \%$ \\
\hline Economics & 24 & $33 \%$ & $8 \%$ & $58 \%$ \\
\hline Computer Science & 19 & $21 \%$ & $16 \%$ & $63 \%$ \\
\hline "Computers" & 27 & $44 \%$ & $7 \%$ & $48 \%$ \\
\hline "I.T." & 25 & $32 \%$ & $0 \%$ & $68 \%$ \\
\hline Other Splits & & & & \\
\hline Males & 33 & $42 \%$ & $9 \%$ & $48 \%$ \\
\hline Females & 63 & $17 \%$ & $22 \%$ & $60 \%$ \\
\hline Black & 42 & $57 \%$ & $2 \%$ & $40 \%$ \\
\hline White & 12 & $0 \%$ & $33 \%$ & $67 \%$ \\
\hline Prev. Disad. School & 46 & $39 \%$ & $4 \%$ & $57 \%$ \\
\hline Prev. Adv. School & 42 & $19 \%$ & $29 \%$ & $52 \%$ \\
\hline
\end{tabular}

Table 5: (After Open Day)

Do you want to major in I.S.?

of winning the competition!). There is likely to be a fair element of this, but it is also likely that the new knowledge of the fact that I.S. existed, offered training in computerrelated subjects in the Commerce Faculty, and was mentioned favourably by friends at the Open Day who were "informed" had also positively affected their thinking. There is a significant difference at the $0.01 \%$ level between those who were informed, and those who weren't, with only $17 \%$ of the informed now definitely not wishing to major in I.S., compared with $47 \%$ of the uninformed. (Chi-squared $=17.03$ with 2 d.o.f., $p=0.0002$ )

\section{Effect of Informing on the Choice of Major}

The second part of Table 5 deals with only those students who hadn't previously considered I.S. and who have now been "informed". Cases where students had previously ringed I.S. as well as other majors are excluded. It shows a high percentage of people considering switching from the
School Students Not Informed at Open Day

\begin{tabular}{|l|c|c|c|c}
\hline & Total & \% Yes & \% No & \% Unsu \\
\hline Female & 48 & $27 \%$ & $40 \%$ & $33 \%$ \\
\hline Male & 12 & $50 \%$ & $17 \%$ & $33 \%$ \\
\hline Black & 30 & $56 \%$ & $17 \%$ & $27 \%$ \\
\hline White & 6 & $0 \%$ & $83 \%$ & $17 \%$ \\
\hline
\end{tabular}

School Students Informed at Open Day

\begin{tabular}{|l|c|c|c|c}
\hline & Total & \% Yes & \% No & \% Unsu \\
\hline Female & 82 & $37 \%$ & $12 \%$ & $51 \%$ \\
\hline Male & 47 & $55 \%$ & $9 \%$ & $36 \%$ \\
\hline Black & 53 & $60 \%$ & $6 \%$ & $34 \%$ \\
\hline White & 16 & $13 \%$ & $6 \%$ & $81 \%$ \\
\hline
\end{tabular}

Table 6: Would you like to be employed in I.S.?

more widely known majors of Accounting or Economics to I.S. (It is possible that many of these are students who did not have particularly strong feelings for these subjects and were therefore more willing to explore alternatives). There are potential converts from Computer Science, and a large proportion of those who had previously indicated the broad area of "computers" and "I.T.", are wanting to change to I.S. In each case fewer than $20 \%$ now say "no" to I.S. as a major, but there is now a great deal of uncertainty $-45 \%$ to $70 \%$ now have something to consider.

Looking at the demographics, males (42\%) appear more willing to convert to I.S. than females (17\%), but there is a huge uncertainty factor $(60 \%)$ amongst the females. There may be various reasons for this, but it appears as if there is an important need for some reinforcement in their minds of the value of an I.S. major. The strongest apparent conversion of all comes from the black students, with 57\% now saying yes, and $40 \%$ being unsure, while a third of the few white students are now unsure. There is also a relatively strong interest shown in moving to I.S. from those attending previously disadvantaged schools.

What about those who had ringed I.S. as one of their possible majors before Open Day? Of the 6 who didn't get "informed", half remained positive and half were now uncertain, while out of 33 who became "informed", 22 still said "yes", and the remainder were now uncertain. They were obviously subject to similar information from various other university disciplines, and it is interesting that not a single "no" was registered. 


\section{Employment in I.S.}

Respondents were also asked "Would you like to be employed in I.S.?"

Overall $42 \%$ said "yes", while $40 \%$ were uncertain (for the informed group these figures were $46 \%$ and $44 \%$ ). Table 6 shows the results for various subgroups. In general there was a slightly higher percentage wanting to be employed in I.S. than wanting to major in it, with correspondingly reduced uncertainty. The characteristics of an I.S. job that apparently appeal to respondents are discussed in other research.

\section{Changing Majors at University}

In 2001 another study was carried out at UCT into the perceptions of students regarding I.S. study and employment. One question asked 266 students from 1st to 4th year whether they had changed majors. The top part of Table 7 shows what percentage of the students had switched from other majors, the most common being Accounting and Computer Science. The second part summarizes the percentage of various groups who have switched to I.S. from other subjects. Those most affected were females, nonEnglish speakers, and those with no prior computer experience. Race was not asked in this survey, and language was used as a rough cultural surrogate - English is not the first language of most of the black students.

The major influencing factors on students' careers were also requested, and can be seen in Table 8. These are seen to be friends for males and for English speakers, parents for females, and career development centers for nonEnglish speakers. The category "other" also included many references to other relatives such as siblings, cousins etc. A different approach is clearly needed for each of the student categories.

\section{Conclusions and Recommendations}

This research indicates that people given improved information on a discipline may have greatly changed intentions of majoring and working in that area. Specifically it reveals that the prevalent lack of knowledge in the previously disadvantaged and female communities in South Africa about the existence or characteristics of I.S. can be relatively easily compensated for, and that this can have a strong influence on students' stated choice of major subject.
Changed to I.S. From:

\begin{tabular}{|l|r|}
\hline Accounting & $8 \%$ \\
\hline Computer Science & $6 \%$ \\
\hline Actuarial Science & $2 \%$ \\
\hline Finance & $2 \%$ \\
\hline Marketing & $2 \%$ \\
\hline Other & $6 \%$ \\
\hline
\end{tabular}

\section{Splits:}

\begin{tabular}{|l|r|}
\hline Female & $33 \%$ \\
\hline Male & $22 \%$ \\
\hline non-English & $35 \%$ \\
\hline English & $23 \%$ \\
\hline Comp. Studies in Grade 12 & $31 \%$ \\
\hline No Comp.Exposure pre UCT & $35 \%$ \\
\hline Computer at Home & $25 \%$ \\
\hline
\end{tabular}

Table 7: Percentage who had switched majors at UCT

Many school students are given no information and encouragement to study computer-related subjects, and when they are, there is often only awareness of the more technical Computer Science degree. Many females in particular feel they are not suited to Computer Science and choose other areas like Accounting. Some embarking on a Computer Science course wish to change midway through their degree to Information Systems.

To attract an increased percentage of female students, a two-stage process is required. Although informing them about I.S. has created many more "yes" responses, the major shift is from "no" to being unsure. This requires further positive reinforcement, and the second study shows that parents are the main influence here. Unless they are informed as well, much of the uncertainty is likely to revert to a "no". Role models can also help here. At UCT the I.S. Department is presently exhibiting its 4 th year systems projects in the main library, with photos showing how well females are represented in the winning teams. In fact, two of the top three this year were female students. 


\begin{tabular}{|l|c|c|c|c|c|}
\hline Influencing Factor & All & Female & Male & Non-Eng & English \\
\hline Friends & $33 \%$ & $21 \%$ & $41 \%$ & $27 \%$ & $36 \%$ \\
\hline Other & $30 \%$ & $27 \%$ & $33 \%$ & $34 \%$ & $29 \%$ \\
\hline Parents & $27 \%$ & $37 \%$ & $20 \%$ & $26 \%$ & $27 \%$ \\
\hline Career Dev. Centre & $18 \%$ & $24 \%$ & $14 \%$ & $31 \%$ & $12 \%$ \\
\hline Teachers & $12 \%$ & $12 \%$ & $12 \%$ & $24 \%$ & $7 \%$ \\
\hline Media & $5 \%$ & $6 \%$ & $5 \%$ & $12 \%$ & $2 \%$ \\
\hline Home Computer & $1 \%$ & $1 \%$ & $1 \%$ & $1 \%$ & $1 \%$ \\
\hline
\end{tabular}

Table 8: Major Influences in Choosing I.S. as a Career

The "newly informed" black students show much enthusiasm, and it appears as if this would result in many more applications to study I.S. A serious problem here is that the Commerce Faculty requires candidates for any degree to have Grade 12 mathematics of a suitable level. Under the previous government's educational system very few black students studied mathematics, and this is taking a long time to rectify. That is a hurdle which needs overcoming. One approach that has been used by UCT for some time is to recruit students who have potential, even if their official school-leaving results do not satisfy the usual criteria. They are then given a special extended program to follow, with additional tutoring. Unfortunately some schools have also not had a very positive attitude towards females studying mathematics. It is therefore also most important, particularly in the previously disadvantaged schools, for teachers and vocational guidance staff to have a reasonable knowledge of I.S. and its opportunities and educational requirements. A video and CD-ROM have been made by the Department of Information Systems where students of different backgrounds themselves discuss I.S., their experiences in studying it, and career opportunities. As a start these have been distributed to a number of local schools and career centers, and there are further plans for its exposure in other ways.

\section{Acknowledgements}

The author would like to acknowledge the National Research Foundation for funding, and thank three I.S. honors students, Ndabezinhle Nkomo, Mandlenkosi Maphumulo and Thabang Ramokoka for assistance with this study.

\section{References}

Bandura, A. (1986). Social Foundations of thought and Action, Prentice Hall, Englewood Cliffs, NJ.

Busch, T. (1995). Gender differences in self-efficacy and attitudes toward computers. Journal of Educational Computing Research, 12(2), 147-158.
Chrisholm, I. M., Irwin, L. \& Carey, J. M. (1998). An International Comparison of Computer Perceptions, Attitudes and Access, [Online], Available:

http://www.coe.uh.edu/insite/elec_pub/HTML1998/di_ch i2.htm, [2001, April 23]

Compeau, D.R. \& Higgins, C.A. (1995). Computer selfefficacy: development of a measure and initial test. MISQ, 19(2), 189-211.

Corston, R. \& Colman, A.M. (1996). Gender and social facilitation effects on computer competence and attitudes towards computers. Journal of educational computing research, 14(2), 171-183.

Divine, R.L., \& Wilson, J.H. (1997). Antecedents of student attitudes toward computers. Journal of Marketing Education, 19(2), 54-67

Gos, M.W. (1996). Computer Anxiety and Computer Experience: A New Look at an Old Relationship. The Clearinghouse, May-June, 69(5), 271-277

Gupta, U.G., \& Houtz, L.E. (2000). High School Students' Perceptions of Information Technology Skills and Careers. Journal of Industrial Technology. (Available at http://www. nait.org/jit/jit.html. Accessed July 2001.)

Hart M.L., Atkins R., Petkar A. \& Webber R. (1999). Student Perceptions of Information Systems as a Field of Work and Study, in Proceedings of the 14th Annual Conference of IAIM. Charlotte, North Carolina, 10 - 12 December, 1999.

Knezek, G., Miyashita, K., Sakamoto, T. (1993). Changes in learning dispositions among students using computers during the first three years of school. North-Holland: Elsevier Science Publishers B. V.

Martin, D., Heller, R., \& Mahmoud, E. (1992). American and Soviet children's attitudes toward computers. Journal of Educational Computing Research, 8(2), 155-185. 
Nielsen, S., von Hellens, L., Greenhill, A. \& Pringle, R. (1997). Conceptualising the influence of cultural and gender factors on students' perceptions of IT studies and careers. Griffith University, Research Reports CIT-9708 .

Sacks, C. (1993). Attitudes toward computers and computer use. Journal of Research on Computing in Education, 26(2), 256-261

Sensales, G. \& Greenfield, P. (1995). Attitudes toward computers, science and technology. Journal of Cross Cultural Psychology, vol. 26, no 3, pp 229-240

Shashaani, L. (1994). Socio-economic status, parents sex-role stereotypes and the gender gap in computing. Journal of Research on Computing in Education, 26(4), 433-441

Staehr, L., Martin, M. \& Byrne, G. (2001). Computer Attitudes and Computing Career Perceptions of First Year Computing Students, Informing Science, June 2001, pp501-509

Taylor, H.G., Mounfield, L.C. (1994). Exploration of the relationship between prior computing experience and gender on success in college computer science. Journal of educational computing research, 11(4), 291-306.
Trauth, E. M., Nielsen, S. H. \& von Hellens, L. A. (2000). Explaining the IT Gender Gap: Australian Stories, [Online], Available:

http://www2.fit.qut.edu.au/ACIS2000/ACIS\%20papers/p aper\%20trauth.pdf, [2001, April 23]

von Hellens, L., Nielsen, S., Greenhill, A. \& Pringle, R. (1998). Cross cultural comparison of students' perceptions of information technology careers. Conceptualising the influence of cultural and gender factors for IS education. Griffith University. Unpublished manuscript.

\section{Biography}

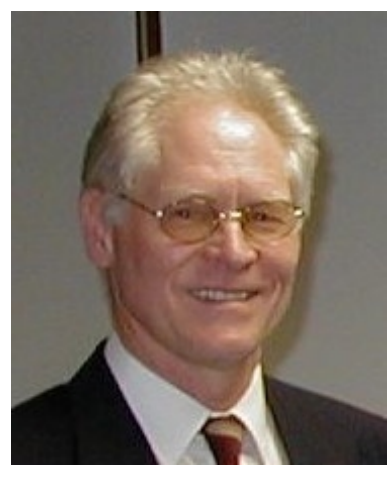

Mike Hart is Associate Professor and current HOD of the Department of Information Systems at the University of Cape Town. He has many years experience in information systems and previously held management positions in retailing, financial services and manufacturing. He currently convenes the fourth year I.S. program, and is involved in other postgraduate areas. His interests are mainly in management aspects and current industry applications of information systems. 